\title{
THE HOLOCENE EVOLUTION OF RHEBAN SPIT, TASMANIA 2. SOIL DEVELOPMENT TRENDS
}

\author{
by G.M. Bowman
}

(with two tables and nine text-figures)

BOWMAN, G.M., 1987 (30:vi): The Holocene evolution of Rheban Spit, Tasmania. 2. Soil development trends Pap. Proc. R. Soc. Tasm., 121, 75-88. https://doi.org/10.26749/rstpp.121.75 ISSN 0080-4703. C.S.I.R.O. Division of Soils, G.P.O. Box 639, Canberra, A.C.T. 2601

Calcareous sands and podzols of four different ages (0,3 100,4200 and 5500 calendar years) form a soil chronosequence at Rheban Spit, a prograded sand barrier, near Orford on the east coast of Tasmania. In terms of profile morphology the soils range from undifferentiated quartz sand with shell at the youngest site, to a well-developed podzol with prominent $\mathbf{A}_{1}, \mathbf{A}_{2}$ and $\mathbf{B}$ horizons at the oldest site. Age trends are derived for a number of soil features, the most significant of which are the leaching from the sediments of detrital marine shell carbonate, the increase in organic matter content in the $\mathrm{A}$ and $\mathrm{B}$ horizons, the decrease in profile $\mathrm{pH}$, the progressive development of $\mathrm{A}_{2}$ and $\mathrm{B}$ horizons in terms of acid-extractable iron and aluminium, the increase in thickness of the B horizon and the decrease in the average concentration of cations in the profiles. Most of these age trends are in accord with those derived from soil chronosequences in New South Wales and overseas, but some are markedly different.

Key Words: Rheban Spit, Tasmania, soil chronosequence, podzols, soil age trends, soil classifica tion, Factual Key.

\section{INTRODUCTION}

Podzol soil profiles are extensively developed in quartzose sandy deposits along the eastern coast of Australia. Early studies at Woy Woy, New South Wales(Burges \& Drover 1953), first identified the potential of these coastal podzols for soil chronosequence investigations (studies of the rate and mode of soil development). However, more systematic investigations of this type have been carried out only relatively recently: Bowman (1979, 1987) concentrated on Holocene sand barrier podzols in New South Wales, while Thompson $(1981,1983)$ and co-workers studied Holocene and Pleistocene podzols in the dune sands of southeastern Queensland.

The progressive increase in age across a Holocene beach-ridge plain provides an ideal spatio-temporal framework for soil chronosequence studies (Bowman 1986a). In such situations, the "time factor" in pedogenesis (Jenny 1941) can be quantified by radiocarbon dating comminuted marine shell deposited with the sediments. The uniformity of the quartzose sands which form the coastal barriers of eastern Australia minimizes complications due to differences in the "parent material" pedogenic factor (Jenny 1946, Bowman 1979). Similarly, the simple ridge/swale morphology of most prograded sand barriers (Thom et al. 1978) allows the "relief factor" to be effectively negated by confining the study to one topographic position, i.e. either ridge crest or mid-swale (Thompson \& Bowman 1984). Vegetation zonation and succession on these barriers have been documented (e.g. McDonald 1971, 1973, Osborn \& Robertson 1939, Pidgeon 1940), allowing the "plant factor" to be assessed without many of the conceptual and practical problems envisaged by soil chronosequence theoreticians (Crocker 1952, Jenny 1958, Olson 1958). In addition, the mild coastal climate of eastern Australia is relatively uniform and unlikely to have changed significantly during the last 7000 years.

This paper expands the literature on eastern Australian podzols by documenting the characteristics and pedogenic development of a soil chronosequence in eastern Tasmania, an area in which such an investigation had not been undertaken previously.

\section{ENVIRONMENTAL SETTING}

The study was carried out on Rheban Spit, a small prograded sand barrier on the eastern coast of Tasmania, in the lee of Maria Island. A complementary paper (Bowman 1986) describes the physical setting, Holocene age structure, geomorphic evolution and sediment characteristics of Rheban Spit, thereby providing the first dated soil chronosequence in Tasmania and pedogenic background data for the present study. 


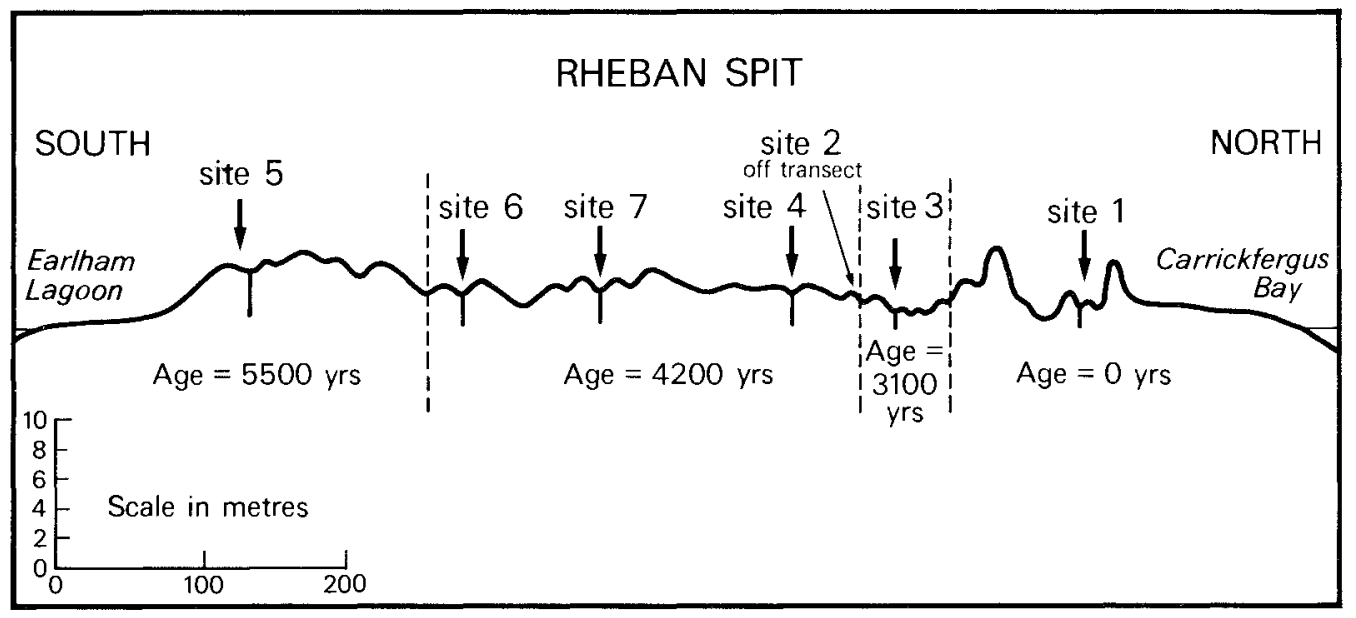

FIG.1 - Cross-section of Rheban Spit showing soil sampling sites 1 to 7 and rounded calendar ages assigned to each (after Bowman 1986).

Monthly rainfall and rainday figures (table 1 ) are based on observations at $R$ heban Farm but the temperature and humidity values relate to Orford, which is located about $10 \mathrm{~km}$ north of R heban Spit. These data show that the area experiences mild summers and cool to cold winters, with a moderate rainfall that is very evenly distributed throughout the year.

The vegetation of Rheban Spit has been described in some detail (Bowden \& Kirkpatrick 1974) as an open forest of Eucalyptus globulus, $E$. viminalis and Acacia dealbata on the uncleared beach-ridge plain, whereas the frontal dunes (where vegetated) carry associations dominated by Banksia marginata, Ammophila arenaria, Pteridium esculentum and various low herbs.

Rheban Spit is composed of well-sorted, fine-to medium-grained, quartzose sand of marine origin. Apart from the sand of the youngest foredunes, which has slightly different characteristics from that of the other depositional units at $\mathrm{R}$ heban, the sediments provide a uniform parent material for soil development. There is only slight variation in mineralogy and granulometry both within and between depositional units (Bowman 1986, tables 3 and 4).

\section{TABLE 1}

\section{Climatic data for Rheban Farm and Orford, Tasmania.} Source: Bureau of Meteorology (1975).

\section{Rheban Farm}

Av, rainfall, $\mathrm{mm}$

Median rainfall, $\mathrm{mm}$

Av. raindays

\section{$\mathbf{M}$}

$\begin{array}{rrrrrrrrrrrrr}48 & 58 & 47 & 47 & 62 & 64 & 52 & 53 & 41 & 55 & 56 & 67 & 650 \\ 42 & 42 & 41 & 37 & 47 & 46 & 46 & 40 & 37 & 49 & 39 & 59 & 590 \\ 9 & 8 & 9 & 9 & 10 & 11 & 11 & 12 & 11 & 11 & 11 & 10 & 122\end{array}$

\section{Orford}

Av. daily max. temp. ${ }^{\circ} \mathrm{C}$

Av. daily min. temp., ${ }^{\circ} \mathrm{C}$

$$
\begin{array}{lllllllllllll}
11.2 & 12.3 & 10.0 & 8.3 & 5.6 & 3.0 & 2.5 & 3.5 & 4.4 & 6.1 & 8.4 & 9.4 & 7.1
\end{array}
$$

Av. daily rel,

humidity, $\%$

$\begin{array}{lllllllllllll}61 & 64 & 56 & 64 & 74 & 79 & 78 & 74 & 61 & 59 & 63 & 59 & 66\end{array}$




\section{METHODS}

\section{Field Sampling}

The seven sites used previously for stratigraphic and sedimentologic analyses (Bowman 1986) were used in the present soil investigation. Six of these were located on the transect line established across the eastern end of the spit by Bowden \& Kirkpatrick (1974) and an additional site was located so as to sample adequately one of the progradational units. The rounded calendar age (in years b.p.) assigned to each sampling site in Part 1 of this paper is here assumed to represent soil age, i.e. the elapsed time since the initiation of soil development at that site (Bowman 1987). Hence, the ages assigned to the soil profiles at Sites 1 to 7 are $0,4200,3100,4200,5500,4200$ and 4200 years, respectively (fig. 1). The identical age of 4200 years for Sites 2, 4, 6 and 7 reduces the number of time-dependent soil profiles in the Rheban chronosequence but still allows the use of profiles of four different ages.

At each site pits were used for description and sampling (at $0.04,0.15$ and $0.3 \mathrm{~m}$ of the upper part of the soil profile) and auger samples were taken at $0.3 \mathrm{~m}$ intervals from the pit floor to the water table. Selected samples were also taken to represent adequately the $A_{1}, A_{2}$ and $B$ horizons. The pedological features of each soil profile were recorded inluding the thickness, lower boundary configuration, structure and dominant colour (Munsell notation) of each horizon.

\section{Laboratory Analyses}

In the laboratory, $\mathrm{pH}$ was measured in a 1:5 water suspension and $10 \%$ hydrochloric acid was used to test for the presence of marine shell carbonate (deposited with the quartzose marine sediments). Total organic matter content of the $<4 \mathrm{~mm}$ fraction was measured by weight loss following low temperature ignition of $2 \mathrm{~g}$ subsamples, previously oven-dried at $105^{\circ} \mathrm{C}$ for 24 hours (inter alios Mitchell 1932). This technique is sufficiently accurate, given the absence of clay minerals in these arenaceous sediments and the furnace temperature being raised to $450^{\circ} \mathrm{C}$, but no higher (Ball 1964). The ashed samples were then digested in hydrochloric acid for 18 hours at 90 $95^{\circ} \mathrm{C}$, using cold finger condensors to minimise evaporation. The resulting digests were filtered, made up to constant volume and the concentrations of six elements were determined by atomic absorption spectroscopy.

\section{RESULTS}

\section{Soil Profile Morphology}

The morphology of the Rheban soils ranges from undifferentiated sand at Site 1, to moderately well-developed podzol profiles towards the landward side of the Spit (Bowman 1986, fig. 2). Selected morphological features of the Rheban profiles are given in table 2 , together with information on shell carbonate occurrence and sample $\mathrm{pH}$. The following general trends may be observed in the data.

$A_{0}, A_{1}, A_{2}, B$ and $C$ horizons are present in all the Rheban profiles, except at Site 1 , where no horizon differentiation could be detected. With the exception of this site, the thickness of the $A_{0}$ and $A_{1}$ horizons is consistent across all the sites, but the $A_{2}$ and $\mathbf{B}$ horizons are of variable thickness, both in absolute terms and in the proportion of total profile depth. Except for the lower boundary of the $\mathrm{A}_{1}$ horizon at Site 3 (classified as "sharp even": Northcote 1979), all other horizon boundaries are "gradational even".

Dominant horizon colours are mostly $10 \mathrm{YR}$ hue, but include some 2.5Y (Munsell Soil Color Charts 1975). Value/chroma ratings for the $A_{1}$ horizons all fall in the $\mathrm{VC} 2$ group (Northcote 1979 ), whereas the $A_{2}$ horizon ratings are in groups 2 and 3 . Although $B$ horizon dominant colours are well clustered, they overlap three value/chroma groups (VC2, 3 and 4).

The field-determined texture of all soil horizons was "sand" and all had "sandy" fabric (Northcote 1979). Parts of the B horizon at Sites 2 , $4,5,6$ and 7 had an "apedal massive" and weakly coherent structure but the remainder of these profiles and the entire soil profile at Sites 1 and 3 had "apedal single grain" structure (Northcote 1979).

\section{Shell Carbonate}

Reaction to the $\mathrm{HCl}$ test for the presence of marine shell carbonate ranged from moderate to strong down the Site 1 profile. However, no samples from above the watertable at the other sites gave a positive reaction.

\section{Soil Reaction}

Sample pH differentiates Sites 1 and 3 from the other soil sites at $\mathrm{R}$ heban. All $\mathrm{pH}$ values for Site 1 were greater than 8.0 (mean $=8.4$ ), with the exception of the surface sample $(\mathrm{pH}=7.3)$. Site 3 
TABLE 2

Soil profile morphology data for Rheban sampling sites.

\begin{tabular}{|c|c|c|c|c|c|c|c|c|c|}
\hline & 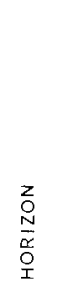 & 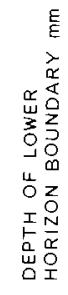 & 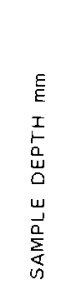 & 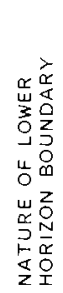 & 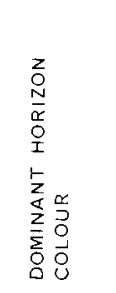 & 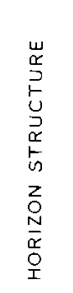 & 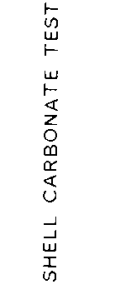 & $\begin{array}{l}I \\
a \\
z \\
O \\
N \\
\frac{N}{2} \\
\\
\end{array}$ & 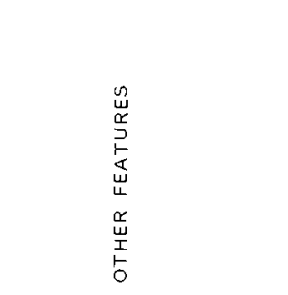 \\
\hline $\begin{array}{l}\text { SITE } 1 \\
A G E=0 \mathrm{yrs} \\
P P F=U \mathrm{c} 1.11\end{array}$ & $\mathrm{Nil}$ & $\rightarrow$ & $\begin{array}{r}40 \\
150 \\
300 \\
610 \\
970 \\
1220 \\
1520\end{array}$ & - & $2.5 Y 7 / 2$ & ASG & \begin{tabular}{|l|} 
Moderate \\
reaction \\
Grading \\
to \\
strong \\
reaction
\end{tabular} & 8.46 & $\begin{array}{l}\text { No surface litter } \\
\text { Few Spinnifex roots } \\
\text { No visible organic matter } \\
\text { Some shell visible, } \\
\text { increasing with depth } \\
\text { Watertable not reached }\end{array}$ \\
\hline $\begin{array}{l}\text { SITE } 3 \\
\text { AGE }=3700 \text { yrs } \\
P P F=U \mathrm{c} 2.21\end{array}$ & $\begin{array}{l}A_{0} \\
A_{1} \\
A_{2} \\
B \\
C \\
\text { W.T. }\end{array}$ & $\begin{array}{r}0 \\
60 \\
150 \\
450 \\
1210\end{array}$ & \begin{tabular}{|c|}
- \\
40 \\
150 \\
\\
300 \\
\\
610 \\
910 \\
1220
\end{tabular} & $\left\{\begin{array}{c}- \\
S-E \\
G-E \\
G-E \\
-\end{array}\right.$ & $\begin{array}{c}- \\
10 Y R 6 / 1 \\
10 Y R 7 / 2 \\
2.5 Y 6 / 4 \\
2.5 Y 7 / 3 \\
10 Y R 7 / 2\end{array}$ & $\begin{array}{c}- \\
\text { ASG } \\
\text { ASG } \\
\text { ASG } \\
-\end{array}$ & $\left\{\begin{array}{l}\mathrm{Nil} \\
\mathrm{Nil} \\
\mathrm{Nit} \\
\mathrm{Nil} \\
\text { Strong }\end{array}\right.$ & $\begin{array}{c}- \\
6.60 \\
6.25 \\
6.40 \\
6.85\end{array}$ & $\begin{array}{l}\text { Decomposing litter } \\
\text { Thin mat of fine roots } \\
\text { and organic material } \\
\text { Few fine roots } \\
\text { Little } 0 . \mathrm{m} \text {. } \\
\text { Very few roots } \\
\text { Little } 0 . \mathrm{m} \text {. } \\
\text { No organic matter } \\
\text { Brown groundwater }\end{array}$ \\
\hline $\begin{array}{l}\text { SITE } 2 \\
A G E=4200 \text { yrs } \\
P P F=U c 2.22\end{array}$ & $\begin{array}{l}A_{0} \\
A_{1} \\
A_{2} \\
B\end{array}$ & $\begin{array}{r}0 \\
100 \\
460 \\
1370\end{array}$ & \begin{tabular}{|r|}
- \\
40 \\
\\
150 \\
300 \\
610 \\
910 \\
1220
\end{tabular} & $\left\{\begin{array}{c}- \\
G-E \\
G-E \\
G-E\end{array}\right.$ & $\begin{array}{l}\text { TOYR } 4 / 1 \\
\text { TOYR } 7 / 2 \\
\text { TOYR } 6 / 4 \\
\text { with } \\
\text { mottles of } \\
\text { TOYR } 6 / 6 \\
\text { TOYR } 7 / 3\end{array}$ & $\begin{array}{c}- \\
A S G \\
A S G \\
A S G \\
A M \\
(100 \\
-130) \\
A S G \\
-\end{array}$ & $\begin{array}{l}\mathrm{Nil}^{-} \\
\mathrm{Nil} \\
\mathrm{Nil}\end{array}$ & $\begin{array}{c}- \\
6.20 \\
5.15 \\
6.25\end{array}$ & $\begin{array}{l}\text { Decomposing itter } \\
\text { Abundant organic matter } \\
\text { Fine matted roots } \\
\text { Few fine roots } \\
\text { Less } 0 . \mathrm{m} \text {. than above } \\
\text { Little visible o.m. } \\
\text { Friable consistency } \\
\text { Few small nodules } \\
\text { No o.m. or roots } \\
\text { Brown groundwater }\end{array}$ \\
\hline $\begin{array}{l}\text { SITE } 4 \\
\text { AGE }=4200 \mathrm{yrs} \\
\mathrm{PPF}=\mathrm{Uc} 2.22\end{array}$ & $\begin{array}{l}A_{0} \\
A_{1} \\
A_{2}\end{array}$ & $\begin{array}{r}0 \\
100 \\
350\end{array}$ & \begin{tabular}{|c|}
- \\
40 \\
150 \\
300 \\
\\
610 \\
910 \\
1220 \\
\\
1520 \\
1830 \\
2130
\end{tabular} & $\begin{array}{c}- \\
G-E \\
G-E\end{array}$ & $\begin{array}{l}\text { - } \\
\text { 10YR } 6 / 2 \\
\text { 10YR } 7 / 2 \\
\text { 10YR } 6 / 4 \\
\text { with } \\
\text { mottles } \\
\text { JoYR } 6 / 5 \\
\text { 10YR } 7 / 3\end{array}$ & $\begin{array}{l}\text { ASG } \\
\text { AM } \\
(76- \\
121) \\
\text { ASG } \\
-\end{array}$ & $\mathrm{Nil}^{-}$ & $\begin{array}{c}- \\
6.10 \\
5.25\end{array}$ & $\begin{array}{l}\text { Decomposing litter } \\
\text { Rich in organic matter } \\
\text { Matted fine roots } \\
\text { Few roots } \\
\text { Little organic matter } \\
\text { evident } \\
\text { Friable consistency } \\
\text { No roots observed } \\
\text { Little organic matter }\end{array}$ \\
\hline
\end{tabular}


TABLE 2 (cont.)

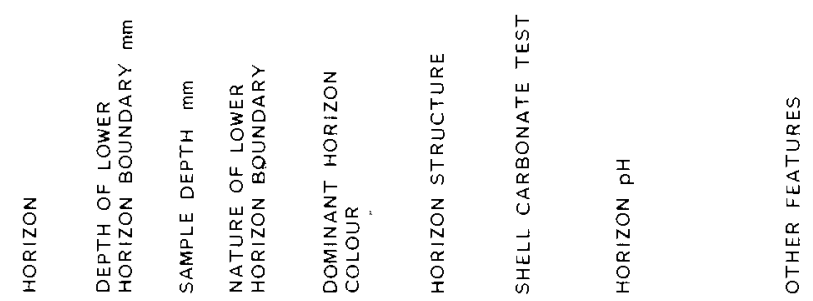

\begin{tabular}{|c|c|c|c|c|c|c|c|c|c|}
\hline \multirow{7}{*}{$\begin{array}{l}\text { SITE } 6 \\
A G E=4200 \mathrm{yrs} \\
\mathrm{PPF}=U \mathrm{c} 2.22\end{array}$} & \\
\hline & $A_{0}$ & 0 & - & - & - & - & - & - & $\begin{array}{l}\text { Decomposing litter } \\
\text { Some charcoal }\end{array}$ \\
\hline & $A_{1}$ & 60 & 40 & $G-E$ & $2.5 Y 5 / 1$ & ASG & $\mathrm{Nil}$ & 6.90 & $\begin{array}{l}\text { Organic matter rich } \\
\text { Fine matted roots }\end{array}$ \\
\hline & $A_{2}$ & 280 & 150 & G-E & $7.5 Y R 7 / 1$ & ASG & $\mathrm{Nil}$ & 5.02 & $\begin{array}{l}\text { Few roots } \\
\text { Little } 0 . \mathrm{m} .\end{array}$ \\
\hline & B & 1520 & $\begin{array}{r}300 \\
610 \\
910 \\
1220 \\
1520\end{array}$ & $G-E$ & $\begin{array}{l}\text { 10YR } 6 / 4 \\
\text { with } \\
\text { mottles of } \\
\text { 10YR } 6 / 5\end{array}$ & $\begin{array}{l}\text { ASG } \\
\text { AM } \\
(46- \\
137) \\
\text { ASG }\end{array}$ & NiI & 5.59 & $\begin{array}{l}\text { Friable consistency } \\
\text { Single large root at } \\
152 \mathrm{~cm} \\
\text { Very little } 0 . \mathrm{m} \text {. }\end{array}$ \\
\hline & $c$ & 2130 & $\begin{array}{l}1830 \\
2130\end{array}$ & - & 10YR $7 / 4$ & - & $\mathrm{Ni}$ & 5.85 & $\begin{array}{l}\text { No o.m. } \\
\text { No roots }\end{array}$ \\
\hline & W.T. & & & & & & $\mathrm{Ni}$ & & Grey-brown Groundwater \\
\hline
\end{tabular}

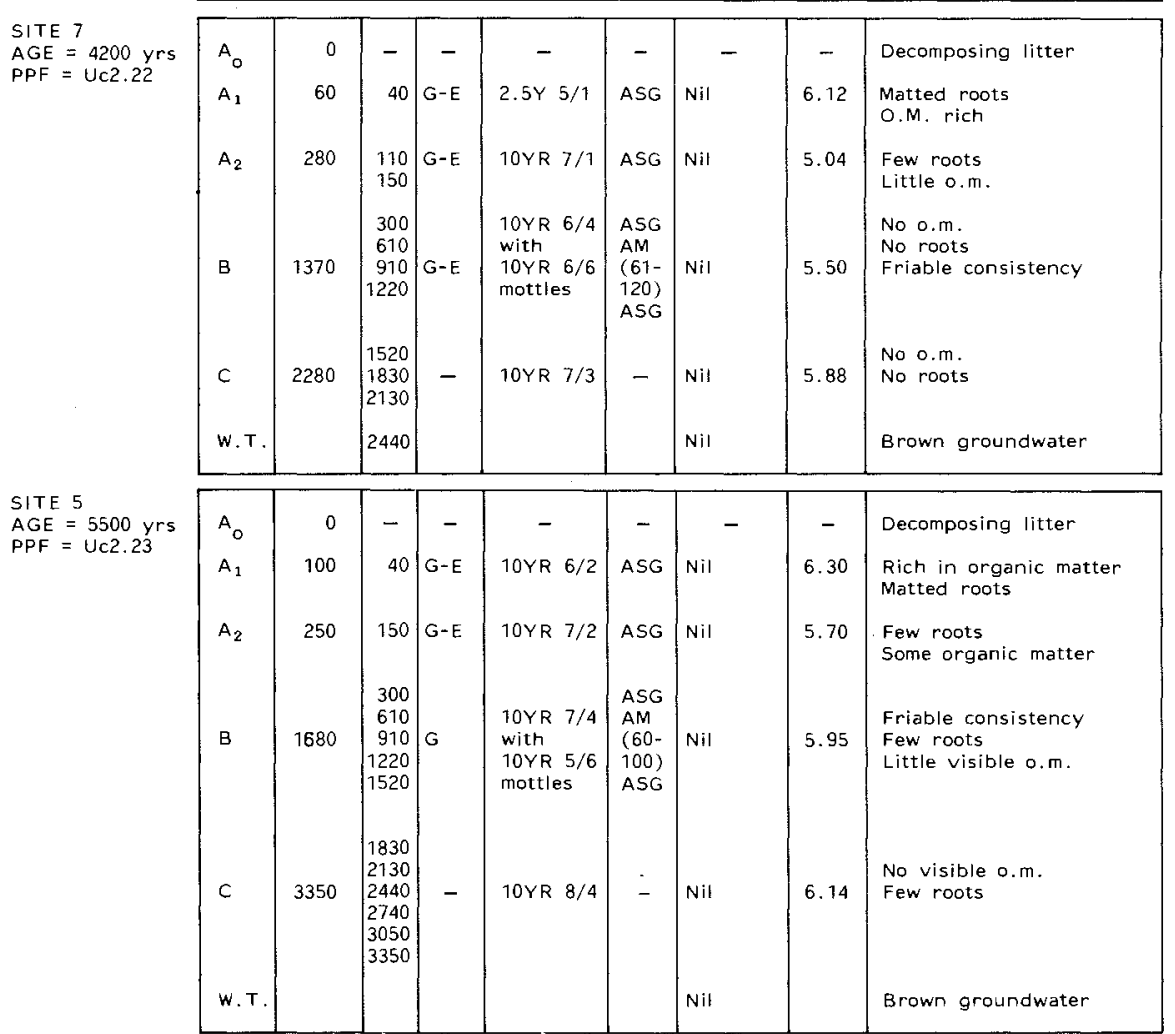

PPF = Principal Profile Form; $A S G=$ apedal single grain; $A M=$ apedal massive $\mathrm{G}-\mathrm{E}=$ gradational-even; $\mathrm{S}-\mathrm{E}=$ sharp-even; $\mathrm{W} . T$. = water table. 


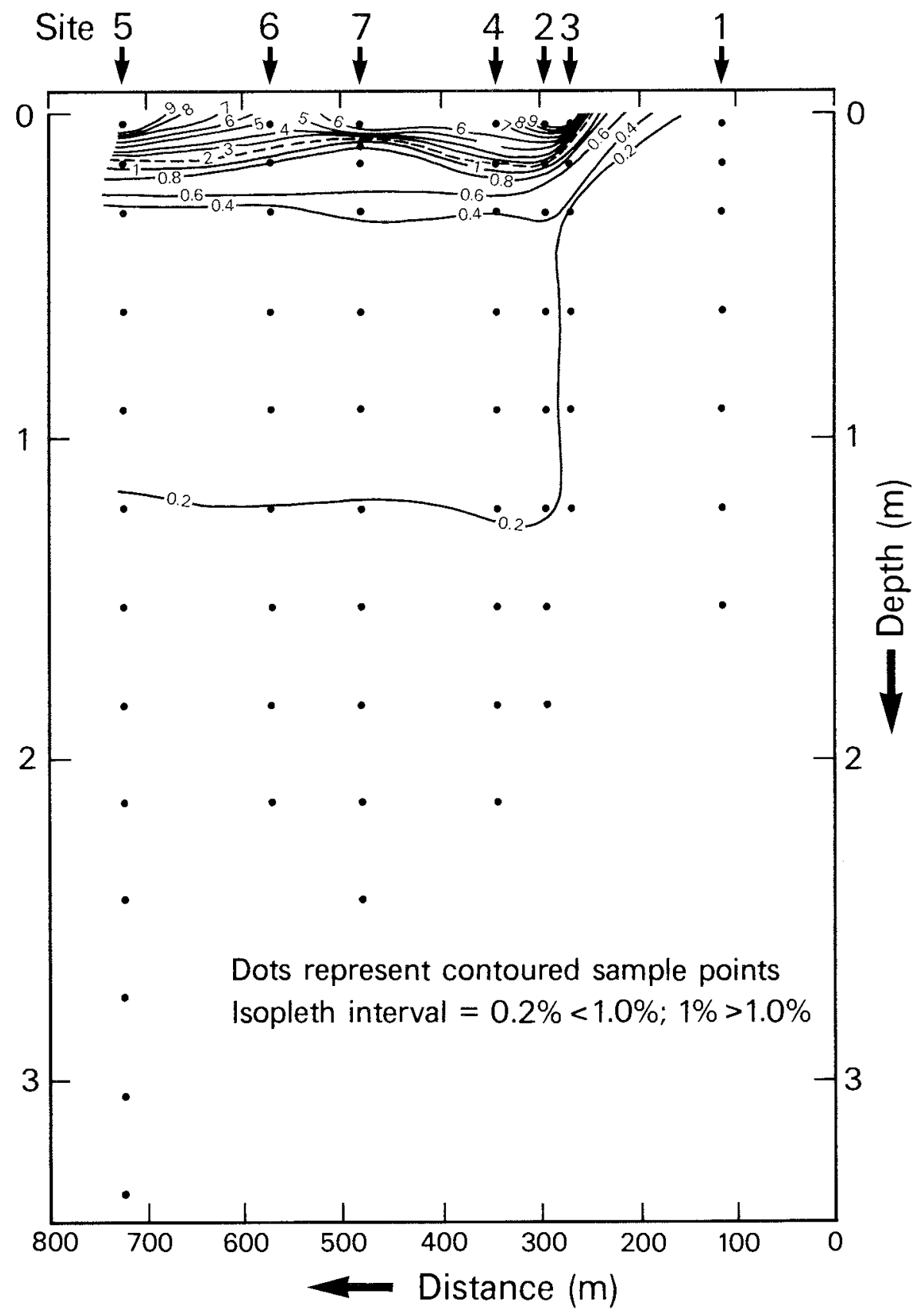

FIG.2 - Contoured cross-section (isogram) showing distribution of organic matter (as \% O.M.) in Rheban Spit soils. Horizontal scale indicates distance from Carrickfergus Bay along section; vertical scale indicates sample depth. Note dual isopleth interval. 
values all exceeded pH $6.0($ mean $=6.9)$, whereas subsurface samples from the remaining sites mostly had $\mathrm{pH}$ values below 6.0 (table 2 ). The mean $\mathrm{pH}$ for all samples from Sites 2, 4, 5, 6 and 7 were 6.1, 5.6, $6.0,5.7$ and 5.6, respectively.

\section{Organic Matter}

Distribution of organic matter in the Rheban soils is depicted in figure 2 by means of an isopleth cross-section (termed an isogram after Ryan \& McGarity 1978). The horizontal axis of the isogram represents distance along the $\mathrm{R}$ heban transect from the Carrickfergus Bay shoreline; the vertical axis shows the depth of sampling points. Dots indicate the organic matter determinations used to construct the isopleths (data from Bowman 1979). A dual isopleth interval was used, with $0.2 \%$ increments up to an organic matter content of $1.0 \%$, and $1.0 \%$ increments above this figure. This arrangement allows both the sharp near-surface changes in organic matter content and the more subtle subsurface transitions to be adequately represented. The main feature of the distribution pattern shown in figure 2 is the very low organic matter content in the subsurface at all sites $(<0.2 \%$ o.m. $)$.

\section{Distribution of Extractable Elements}

Results of the analyses of hydrochloric acidextractable cations are presented as isograms in figure 3 (after Bowman 1979). Note that some of these isograms use a geometric isopleth ratio while others use an arithmetic isopleth interval to best portray the element distribution patterns. However, all isograms have the same horizontal and vertical scales. In deriving element age trends for the Rheban chronosequence (see below), the element distribution patterns were used to select concentrations representative of the $A_{1}, A_{2}, B$ and $C$ horizons at each soil site. The main features of the element distribution patterns shown in figure 3 are:

\section{Iron}

All profiles landward of Site 3 exhibit moderate development of both $\mathrm{A}_{2}$ and $\mathrm{B}$ horizons (in terms of iron distribution), although the $A_{2}$ horizon at Site 7 appears anomalously thin (fig. 3A). A pronounced discontinuity exists in the upper profile between Sites 1 and 3, with another between Sites 2 and 3. These probably reflect the age differences between the successive progradational units at Rheban. Below a depth of $1 \mathrm{~m}$ however, iron distribution forms a relatively systematic pattern across Rheban Spit. The exception is a small irregularity near the base of Site 2, possibly caused by a minor concentration of heavy minerals (but not evident in sand grain counts: Bowman 1986, table 4).

\section{Manganese}

Relatively high concentrations of acidextractable $\mathrm{Mn}$ are evident in the upper soil profiles except at Site 1 (fig. 3B). Vertical discontinuities occur on either side of Sites 3 and 7 but the distribution of manganese in the subsurface is relatively uniform.

\section{Aluminium}

As with the iron distribution pattern, pronounced vertical discontinuities are apparent between Sites 1 and 3 and between Sites 2 and 3, and at the surface between Sites 2 and 4 (fig. 3C). Otherwise, there is a systematic distribution of aluminium across the other sites with only slight irregularities around Site 7. Development of the $A_{2}$ horizon is prominent across Sites 4, 5, 6 and 7, and accumulation of aluminium in the B horizon is evident at Sites 5 and 6 , and to a lesser extent at Sites 2, 4 and 7 .

\section{Calcium}

Apart from Site 1, relatively high calcium values occur near the ground surface, reflecting the distribution of organic matter in the soil profiles (fig. 3D). Below the near-surface accumulation calcium values are much lower, probably indicating an eluviated horizon (except at Site 7). On the other hand, development of an illuvial B horizon is not evident in the calcium distribution pattern. Relatively high calcium values at depth at Site 1 , and somewhat lower concentrations at Site 3, probably represent unleached detrital shell carbonate. In contrast, this has been completely removed from the older soil profiles, except near the water table.

\section{Magnesium}

Concentrations of magnesium are low in all the Rheban soil profiles and the distribution pattern is uniform, with little evidence of near-surface accumulation (fig. 3E). As with the distribution of calcium, the pattern indicates an eluviated horizon low in acid-extractable magnesium, except for an anomaly associated with Site 7 . Magnesium distribution appears little affected by local concentrations of shell or weatherable minerals.

\section{Sodium}

The analyses indicate that this cation is very regularly distributed across $\mathrm{R}$ heban $\mathrm{Spit}$, with a thin eluviated horizon present at Sites 5, 6 and 7 

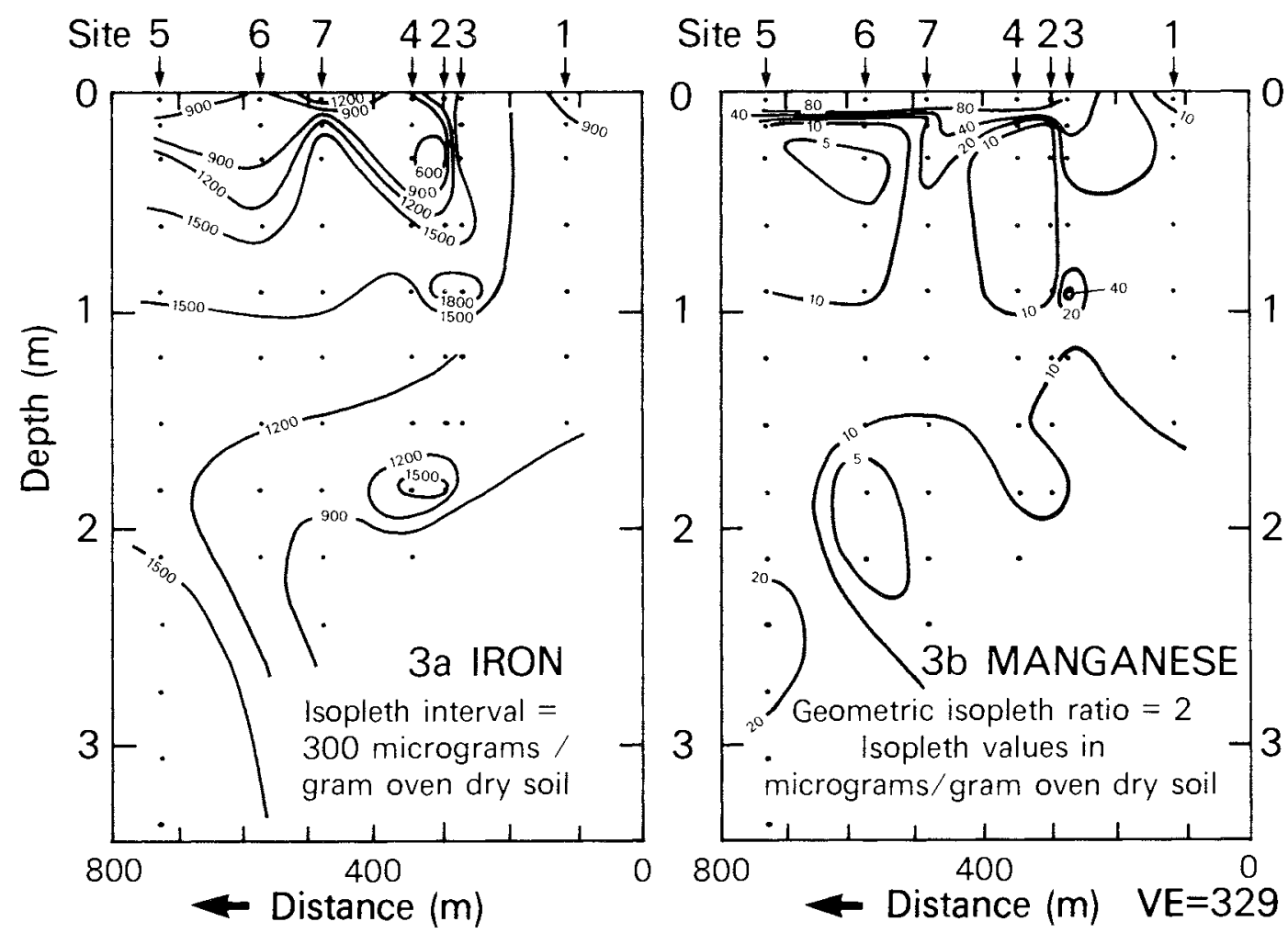

FIG.3 - Isograms showing distribution of acid-extractable iron, manganese, aluminium, calcium, magnesium and sodium in the Rheban soil profiles. Note different isopleth intervals and ratios.

(fig. 3F). Higher sodium concentrations occur in the lower parts of some profiles (reflecting saline groundwater) and irregularly down the Site 1 profile, probably as a result of high aerosol input of marine salt adjacent to Carrickfergus Bay (fig. 1).

\section{DISCUSSION}

\section{Soil Classification}

Using the Australian great soil group system to classify the R heban soil profiles, the undifferentiated sediments at Site 1 constitute a "calcareous sand", but the profiles at all the other sites fall within the "podzol" great group (Stace et al. 1968). Insufficient data exist to satisfy the criteria for a spodic B horizon using the FAO-UNESCO (1974) classification. Therefore, none of the Rheban profiles may be classed as a "podzol" under this scheme; all are "arenosols". Thus, both great soil group classifications are relatively insensitive to the degree of development of the podzols at Rheban and do not adequately distinguish the profiles in terms of the established age sequence.

In contrast, the Factual Key of Northcote (1979) classifies the profiles into a developmental sequence which relates to soil age, even though the profiles all key into the coarse-textured subdivision of the "uniform" primary profile form (i.e. Uc: Northcote 1979). The undifferentiated sands at Site 1 (age $=0$ years) are classed as a "calca reous sand" (principal profile form $=\mathrm{Uc1} 1.11$ ), whereas the Site 3 profile (age $=3100$ years) displays an incipient "bleached $\mathrm{A}_{2}$ with colour B horizon" (Uc2.21).

Sites $2,4,6$ and 7 (all $=4200$ years) are also classed as "bleached sands with colour B horizons", but are grouped on the basis of their B horizon value/ chroma ratings as Uc2.22. The Site 5 soil profile (age $=5500$ years) is also a "bleached sand", but is differentiated from the Uc2.22 profiles on the basis of the colour of the B horizon mottles ( $\mathrm{Uc2} 2.23$ : Northcote 1979, Northcote et al. 1975). 

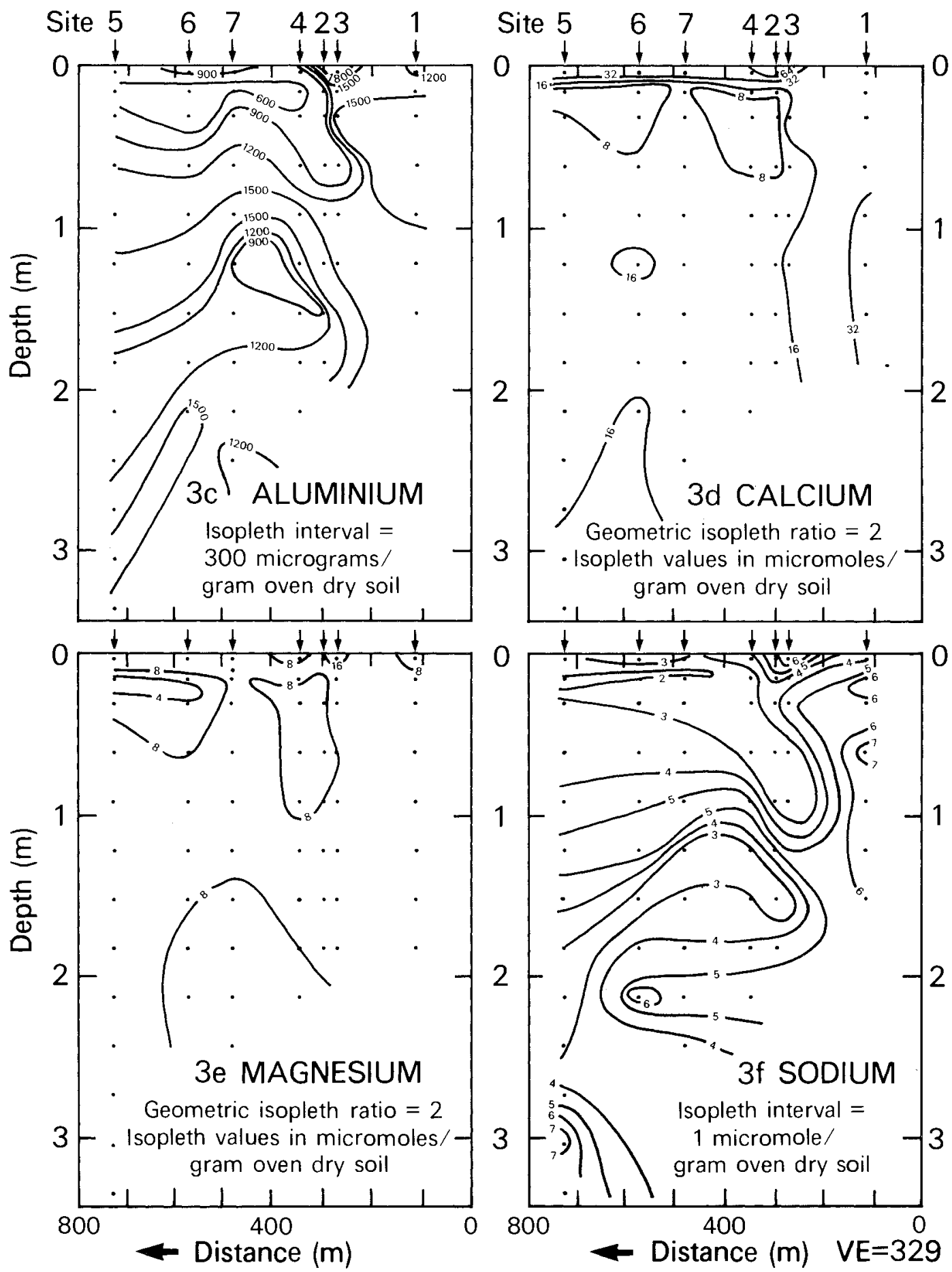

FIGURE 3 (cont.) 
Insufficient chemical and micromorphological data are a vailable to classify the Rheban soils adequately using the U.S. Soil Taxonomy (Soil Survey Staff 1975). However, from field observations and the analytical results presented above it seems unlikely that any of the Rheban soils would qualify as a "Spodosol", the Soil Taxonomy equivalent of a podzol (McKeague et al. 1983 , Thompson \& Hubble 1980).

\section{Age Trends}

The Rheban soil chronosequence and the age trends derived from it are based on four dated soil sites: a modern soil profile, two radiocarbon dated profiles and a composite soil profile consisting of averages obtained from the four soil profiles assigned identical ages in Part 1 of this study (Bowman 1986).

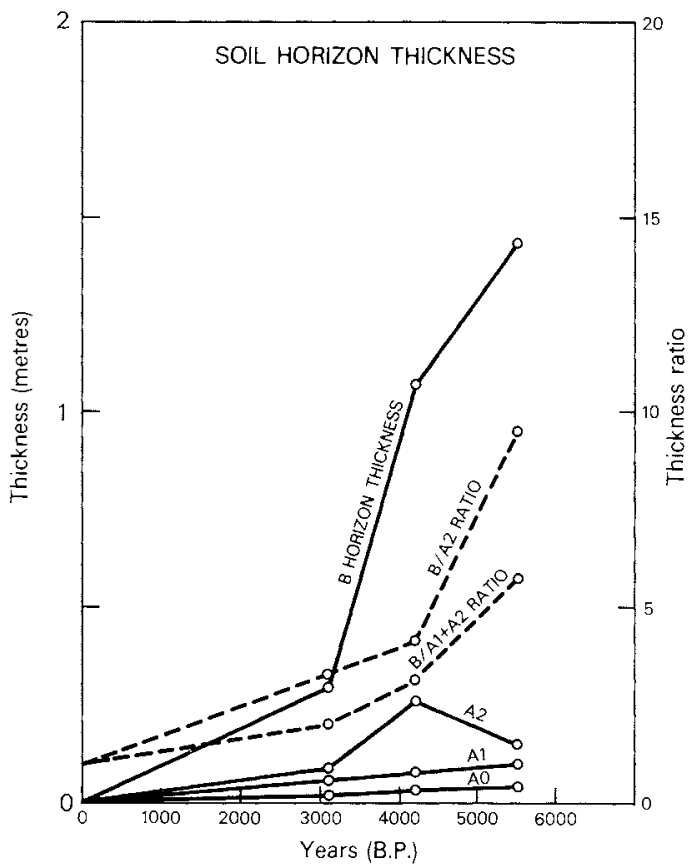

FIG.4 - Plot against soil age of horizon thickness and horizon thickness ratios for the Rheban profiles.

The profile morphology data in table 2 indicate that several progressive changes occur with increasing profile age. For example, some thickening is apparent in the $A_{1}$ and $A_{2}$ horizons, but this trend is slight in comparison with the pronounced development of the B horizon. Con- sequently, plots of horizon thickness ratios against age show a systematic increase if the $\mathbf{B}$ horizon is included (fig. 4), but not otherwise. Similar increases with age in the thickness of podzol horizons have been reported from chronosequences overseas (e.g. Jenny 1941, Olson 1958, Franzmeier \& Whiteside 1963, Birkeland 1984, Rockwell et al. 1985 ) and from eastern Australia (Burges \& Drover 1953, Thompson \& Hubble 1980, Thompson 1981, Thompson \& Bowman 1984, Bowman 1987).

The dominant colours of the R heban profiles do not appear to change systematically with soil age. This differs from trends recorded in other chronosequences in which colour (particularly of the B horizon) was found to darken, deepen or redden with increasing soil age (e.g. Dickson \& Crocker 1954, Brewer \& Thompson 1980, Birkeland 1984, Thompson \& Bowman 1984). Further analysis of the Rheban data to quantify better the contrast between the dominant colours of the $A_{0}$, $\mathrm{A}:$ and $\mathrm{B}$ horizons in terms of colour distance units (Bowman 1979) also failed to vield systematic age trends similar to those obtained from a comparable podzol chronosequence in New South Wales (Bowman 1987). Also, the ubiquitous gradationaleven $\mathrm{A}$ :-B horizon transition in the $\mathrm{R}$ he ban profiles contrasts with observations on the mainland (Bowman 1979, Thompson \& Bowman 1984), where coastal podzols older than 4500 years invariably display sharp-irregular $\mathrm{A}$ :-B horizon boundary configurations.

However, the $\mathrm{pH}$ data from $\mathrm{Rheban}$ do yield systematic age trends, with horizon $\mathrm{pH}$ and average profile $\mathrm{pH}$ tending to decrease with age (fig. 5). The $B$ horizon trend is in good agreement with that obtained for New South Wales podzols, but the $\mathrm{pH}$ values of the $\mathrm{C}$ horizon are somewhat lower than the corresponding figures for New South Wales (fig. 5). This decrease in soil $\mathrm{pH}$ with increasing age has been reported in many chronosequence studies of young, freely-drained soils (e.g. Salisbury 1925, Hissink 1938, Crocker \& Major 1955, Olson 1958, Franzmeier et al. 1963, Stevens \& Walker 1970). The age trend relates to the build-up of organic matter and the production of humic and fulvic acids, resulting in the progressive leaching of carbonate (where present) and mobile bases (Stevens \& Walker 1970).

The lack of detrital shell in all the Rheban profiles except Site 1, probably indicates extensive leaching from the older sand deposits. Hence, the complete removal of visible shell from the sediment at Site 3 during the 3100 years since its deposition, provides a measure of the maximum time required for complete carbonate leaching at Rheban. As 


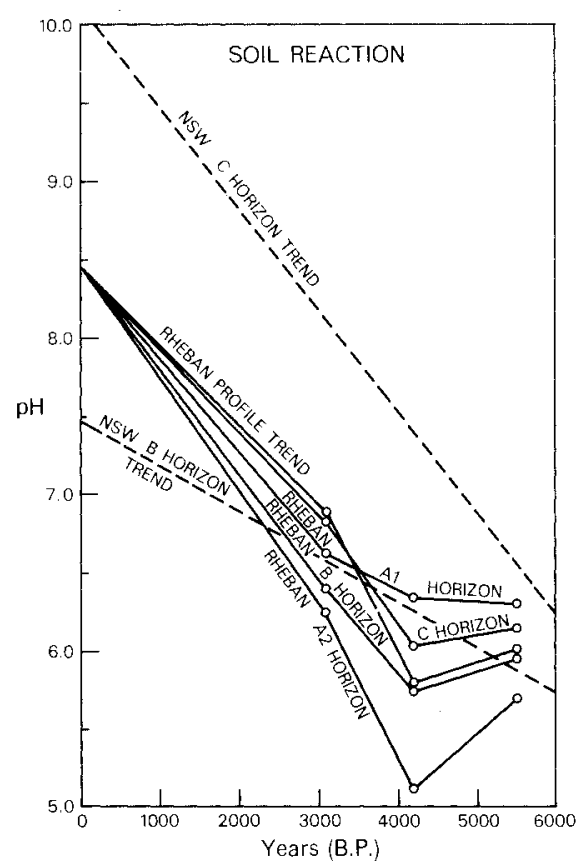

FIG.5 - Soil age:pH plots of average profile $p H$ and horizon $p H$ for Rheban and New South Wales podzols. Origin of Rheban graphs is mean of $\mathrm{pH}$ values for Site 1 ( $=0$ years). Rheban profile trend derived from mean $p H$ of samples from each site. New South Wales regression trends in figures 5, 6, 7 and 8 from Bowman (1987).

Thompson \& Bowman (1984) noted, the rate of removal of shell carbonate largely depends on the initial size of fragments and will vary locally. However, rates determined in comparable chronosequence studies using better short-term age control do accord with the Rheban estimate (e.g. Olson 1958).

There is good agreement between the age trend for $\mathbf{B}$ horizon organic matter content in the Rheban chronosequence and in New South Wales coastal podzols (fig. 6; Bowman 1987). Other measures of organic matter content in the Rheban profiles also increase with age (notably the $A_{1}$ horizon content: fig. 6 ), indicating accumulation of organic matter in the chronosequence. This agrees with northern hemisphere observations, and there is some evidence from R heban for attainment of a "steady state" situation in organic matter gains and losses, as suggested by studies overseas (e.g. Crocker \& Dickson 1957, Jacobson \& Birks 1980, Jenny 1980, Ellis \& Richards 1985).
Systematic age trends are evident in the concentrations in the Rheban samples of some acidextractable elements. Extractable aluminium in the $A_{2}$ horizon progressively decreases with time, whereas in the $\mathrm{B}$ horizon it increases (fig. 7). Hence, the $\mathrm{B} / \mathrm{A}_{2}$ ratio for aluminium rises with increasing profile age, reflecting progressive soil development and chemical differentiation of podzol horizons. However, the mean aluminium concentration in the Rheban profiles decreases with age (fig. 7), indicating net loss of this cation from the soil. These trends are in agreement with New South Wales results, but the $B$ horizon concentrations of aluminium at $R$ heban are substantially higher than the corresponding New South Wales averages, probably reflecting differences in parent material rather than organic matter accumulation.

Consistent age trends are not immediately evident in the distribution of acid-extractable iron in the Rheban chronosequence, mainly because the values for this cation are anomalously high in all horizons at Site 3 (fig. 8). This could be attributed to the pedogenic effects of the comparatively low topographic position of Site 3 (and hence relatively high water table) causing apparent compression of the soil profile (Thompson \& Hubble 1980). However, if horizon concentration ratios for iron are examined, the $B / A_{2}$ ratio (for example) shows a consistent increase with age and is accordant with the $B / A_{2}$ age trend for New South Wales coastal podzols (fig. 8 and Bowman 1987).

The progressive leaching of both calcium and sodium from the R heban chronosequence is evident in a plot against age of the average profile concentration of these cations (fig. 9). While this trend is the same as that observed in New South Wales podzols, the increase in calcium in the $A_{1}$ horizon at Rheban with increasing soil age (fig. 9) is the reverse of the New South Wales trend (Thompson \& Bowman 1984, Bowman 1987). In addition, no manga nese or magnesium age trends were identified in the Rheban chronosequence, although such trends have been recognized in New South Wales (Bowman 1979).

\section{CONCLUSION}

A soil chronosequence of four ages and four stages of development ranging from calcareous sands to podzols has evolved in the sediments of Rheban Spit. Classification of the profiles according to the Australian great soil groups (Stace et al. 1968) does not effectively separate the soils on the basis of age: this is better achieved by $A$ Factual Key (Northcote 1979). 


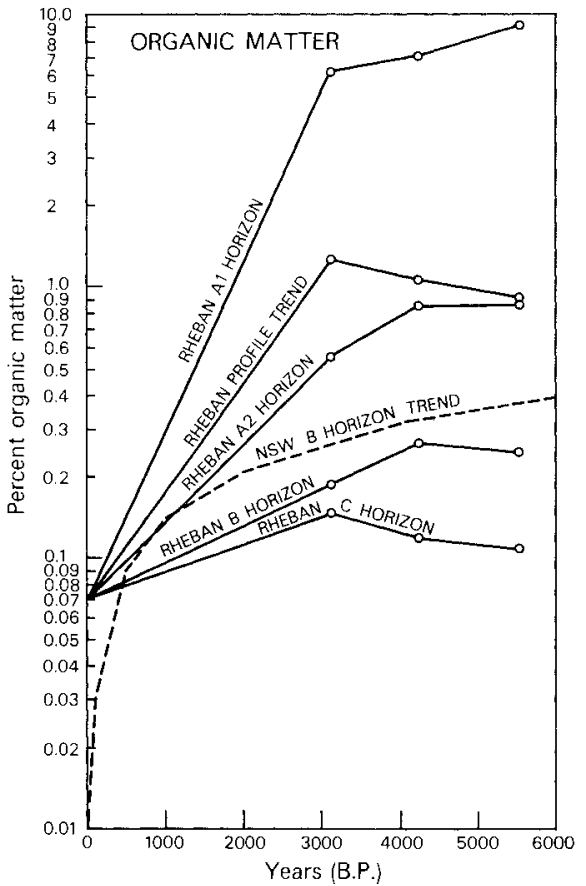

FIG.6 - Plot of organic matter content against soil age for Rheban and New South Wales profiles. Note: log scale used on the ordinate.

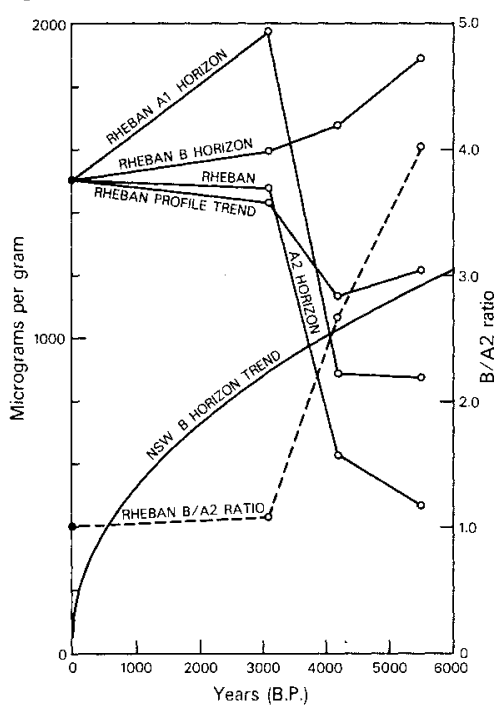

FIG.7 - Plot of acid-extractable aluminium against soil age for Rheban and New South Wales profiles. Origin of Rheban graphs is mean aluminium concentration in Site 1 samples. Rheban $B / A_{2}$ ratio refers to the ratio of acid-extractable aluminium in those horizons.

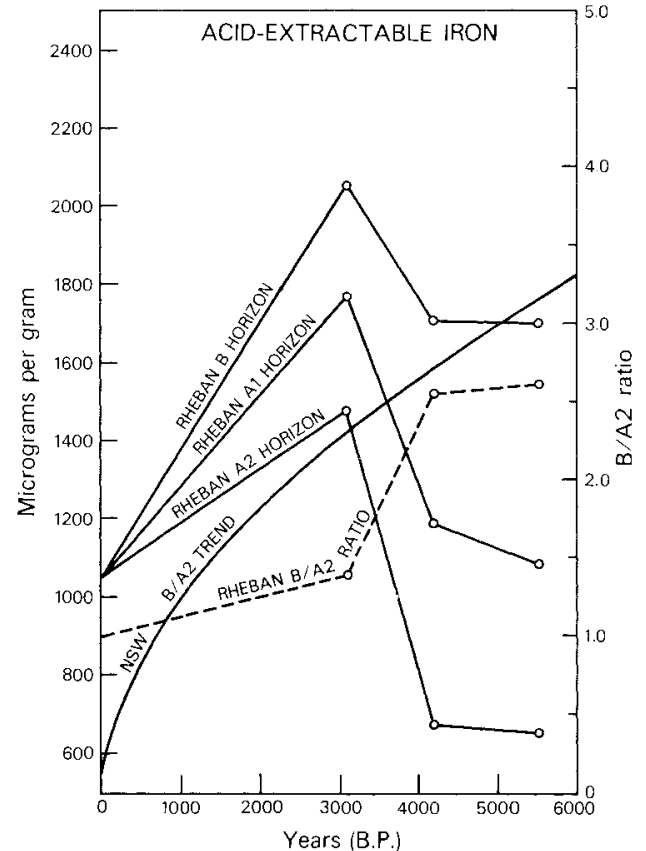

FIG.8 - Plot of acid-extractable iron against soil age for Rheban and New South Wales profiles. Origin of Rheban graphs is mean iron concentration in Site 1 samples. Rheban $B / A_{2}$ ratio refers to the ratio of acid-extractable aluminium in those horizons.

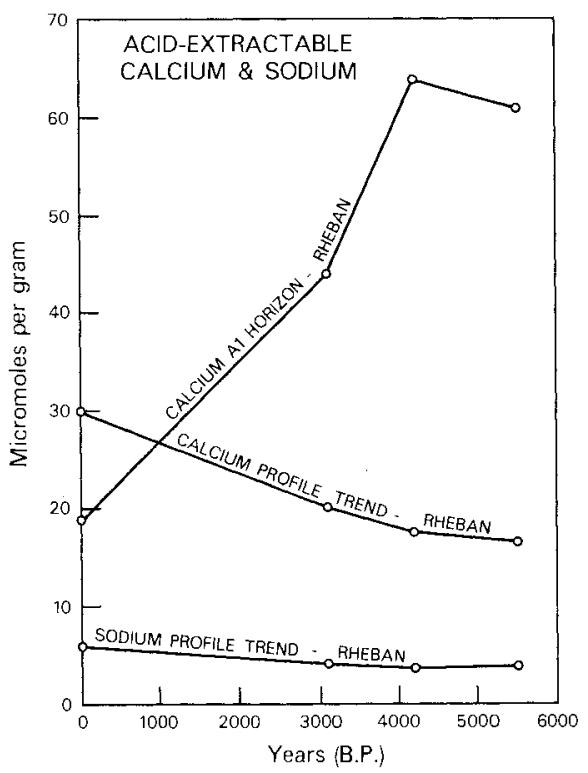

FIG.9 - Plot of acid-extractable calcium and sodium against soil age for Rheban soils. 
Age trends are evident in a range of soil features recorded and measured in the Rheban soils. The most prominent of these are the leaching of marine shell carbonate, the accumulation of organic matter in the soils, the acidification of the profiles, the mobilisation of several acid-extractable elements and the thickening of the $\mathrm{B}$ horizon with increasing soil age. The soil horizons have become increasingly differentiated in terms of iron and aluminium distribution, while the average content of these elements in the profiles has decreased. In general, the age trends are in accord with those evident in a comparable podzol chronosequence in New South Wales and with similar overseas studies.

\section{ACKNOWLEDGEMENTS}

The writer thanks Suzanne Bowman for field assistance and Dr B.G. Davey of the Department of Soil Science, University of Sydney for the provision of facilities for AAS analysis. Dr G.G. Beckmann, Mr C.H. Thompson and Mr K.D. Nicolls kindly refereed drafts of this paper.

\section{REFERENCES}

BALL, D.F., 1964: Loss-on-ignition as an estimate of organic-matter and organic carbon in noncalcareous soil. J. Soil Sci., 15: 84-92.

BIRKELAND, P.W., 1984: SOILS AND GEOMORPHOLOGY. Oxford University Press, New York.

BOWDEN, A.R. and KIRKPATRICK, J.B., 1974: The vegetation of the Rheban Spit, Tasmania. Pap. Proc. R. Soc. Tasm., 108: 199-210.

BOWMAN, G.M., 1979: DEVELOPMENT OF PODZOL SOILS IN EAST AUSTRALIAN COASTALSAND BARRIERS. Unpubl. Ph.D. thesis, University of Sydney.

BOWMAN, G.M., 1986: The Holocene evolution of Rheban Spit, Tasmania. 1. Age structure, geomorphic development and sediment characteristics. Pap. Proc. R. Soc. Tasm., 120: 23-32.

BOWMAN, G.M., 1987: Pedochronology: potential for age determination of archaeological sites. In Ambrose, W. (Ed.): ARCHAEOMETRY: FURTHER STUDIES IN AUSTRALASIA. Proc. 2nd Aust. Archaeometry Conf., ANU/ ANG, Canberra, 1985.

BREWER, R.\& THOMPSON, C.H., 1980: Morphology of two sub-tropical podzols formed on a siliceous dune in coastal Queensland. In Joseph, K.T. (Ed.): Proc. Conf. Class. Manage. Trop. Soils, Malays. Soc. Soil Sci: 116-123.

BUREAU OF METEOROLOGY, AUSTRALIA, 1975 . CLIMATIC AVERAGES, AUSTRALIA. Metric edition. Australian Government Publ. Service, Canberra.
BURGES, A. \& DROVER, D.P., 1953: The rate of podzol development in the sands of the Woy Woy district, N.S.W. Aust J. Bot, 1: 83-94.

CROCKER, R.L., 1952: Soil genesis and the pedogenic factors. Quart. Rev. Biol., 27: 139-168.

CROCKER, R.L. \& DICKSON, B.A., I957: Soil development on the recessional moraines of the Herbert and Mendenhall glaciers, southeastern Alaska. J. Ecol., 45: 169-185.

CROCKER, R.L.\& MAJOR, J., 1955: Soil development in relation to vegetation and surface age at Glacier Bay, Alaska. J. Ecol., 43: 427-448.

DICKSON, B.A. \& CROCKER, R.L., 1954: Chronosequence of soils and vegetation near $\mathrm{Mt}$. Shasta California,III. Some properties of the mineral soils. J. Soil Sci, 5: 173-191.

ELLIS, S. \& RICKARDS, K.S., 1985: Pedogenic and geotechnical aspects of Late Flandrian slope instability in Ulvadalen, west-central Norway. In Richards, K.S., Arnett, R.R.\& Ellis, S.(Eds): GEOMORPHOLOGY AND SOILS. George Allen \& Unwin, Lond on: 328-347.

FAO-UNESCO, 1974: SOIL MAP OF THE WORLD. VOL. 1: $L E G E N D$. UNESCO, Paris.

FRANZMEIER, D.P. \& WHITESIDE, E.P., 1963: A chronosequence of podzols in northern Michigan. 2. Physical and chemical properties. Mich. State Univ. Agl. Expl. Station Quart. Bull., 46: 21-36.

FRANZMEIER, D.P., WHITESIDE, E.P. \& MORTLAND, M.M., 1963: A chronosequence of podzols in northern Michigan. 3. Mineralogy, micromorphology and net change occurring during soil formation. Mich. State Univ. Agl. Expl. Station Quart. Bull., 46: 37-57.

HISSINK, D.J., 1938: The reclamation of the Dutch saline soils (Solonchak) and their further weathering under humid climatic conditions of Holland. Soil Sci., 45: 83-94.

JACOBSON, G.L. \& BIRKS, H.J.B., 1980: Soil development on recent end moraines of the Klutlan Glacier, Yukon Territory, Canada. Quat. Res., 14: $87-100$.

JENNY, H., 1941: FACTORS OF SOIL FORMATION. McGraw-Hill, New York.

JENNY, H., 1946: Arrangement of soil series and types according to functions of soil-forming factors. Soil Sci., 61: 375-391.

JENNY, H., 1958: Role of the plant factor in the pedogenic functions. Ecology, 39: 5-16.

JENNY, H.,1980: THE SOIL RESOURCE. SpringerVerlag, New York.

McDONALD, K., 1971:The zonal vegetation of One Mile Beach, Anna Bay. Hunter Natural History, 3: 119-135.

McDONALD, K., 1973: Coastal sand dune ecology: field phenomena and interpretation. Aust. Sci. Teach. J., 19: 33-45

MITCHELL, J., 1932: The origin, nature and importance of soil organic constituents having base exchange properties. J. Amer. Soc. Agron., 24: 256-275. 
McKeAgue, J.A., DeCONINCK, F. \& FRANZMEIER, D.P., 1983: Spodosols. In Wilding, L.S., Smeck, N.E. \& Hall, G.F. (Eds): $P E D O-$ GENESIS AND SOIL TAXONOMY. II. THE SOIL ORDERS. Elsevier, Amsterdam: 217-252.

MUNSELL SOIL COLOR CHARTS, 1975: Munsell Color, Baltimore.

NORTHCOTE, K.H., 1979: A FACTUAL KEY FOR THE RECOGNITION OF AUSTRALIAN SOILS. 4th Edition. Rellim Tech. Publs, Adelaide.

NORTHCOTE, K.H., HUBBLE, G.D., ISBELL, R.F., THOMPSON, C.H. \& BETTENAY, E., 1975: A DESCRIPTION OF AUSTRALIAN SOILS. CSIRO, Australia.

OLSON, J.S., 1958: Rates of succession and soil changes on southern Lake Michigan sand dunes. Bot. Gaz., 119: 125-170.

OSBORN, T.G.B. \& ROBERTSON, R.N., 1939: A reconnaissance survey of the vegetation of the Myall Lakes. Proc. Linn. Soc. N.S.W., 64: 279-296.

PIDGEON, I.M., 1940: The ecology of the central coastal area of New South Wales. III. Types of primary succession. Proc. Linn. Soc. N.S.W., 65: 221-236.

ROCKWELL, T.K., JOHNSON, D.L., KELLER, E.A. \& DEMBROFF, G.R., 1985: A Late Pleistocene-Holocene soil chronosequence in the Ventura Basin, southern California, U.S.A. In Richards, K.S., Arnett, R.R. \& Ellis, S. (Eds): GEOMORPHOLOGY AND SOILS. George Allen \& Unwin, London: 309-327.

RYAN, P.J. \& McGARITY, J.W., 1978: Spatial variability of soil properties under forest species. Paps Aust. Soil Sci. Soc. N.S.W. Branch Conf., Armidale: 9-19.

SALISBURY, E.J., 1925: Note on the edaphic succession in some dune soils with specific reference to the time factor. J. Ecol., 13: 322-328.
SOIL SURVEY STAFF, 1975: SOIL TAXONOMY. A BASIC SYSTEM OF SOIL CLASSIFICATION FOR MAKING AND INTERPRETING SOIL SURVEYS. USDA Agric. Handbook No.436.

STACE, H.C.T., HUBBLE, G.D., BREWER, R., NORTHCOTE, K.H., SLEEMAN, J.R,, MULCAHY, M.J. \& HALLSWORTH, E.G., 1968: A HANDBOOK OF AUSTRALIAN SOILS. Rellim Tech. Publs, Glenside, South Australia.

STEVENS, P.R.\& WALKER, T.W., 1970: The chronosequence concept and soil formation. Quart. Rev. Biol., 45: 333-350

THOM, B.G., POLACH, H.A. \& BOWMAN, G.M., 1978: HOLOCENE AGE STRUCTURE OF COASTAL SAND BARRIERS IN NEW SOUTH WALES. Geography Department, University of New South Wales, Duntroon.

THOMPSON, C.H., 1981: Podzol chronosequences on coastal dunes of eastern Australia. Nature, 291: 59-61.

THOMPSON, C.H., 1983: Development and weathering of large parabolic dune systems along the subtropical coast of eastern Australia. Z. Geomorph., 45: 205-225.

THOMPSON, C.H. \& BOWMAN, G.M., 1984: Subaerial denudation and weathering of vegetated coastal dunes in eastern Australia. In Thom, B.G. (Ed.): COASTAL GEOMORPHOLOGY IN AUSTRALIA. Academic Press, Sydney: 263-290.

THOMPSON, C.H. \& HUBBLE, G.D., 1980: Subtropical podzols (spodosols and related soils) of coastal eastern Australia. In Joseph, K.T. (Ed.): Proc. Conf. Class. Manage. Trop. Soils, Malays. Soc. Soil Sci.: 203-213.

(accepted 3 March 1987) 